\title{
Husband's Support towards Unmet Need of HIV Positive-Infected Women of Childbearing Age
}

\author{
Dukungan Suami terhadap Unmet Need pada Wanita Usia Subur dengan \\ HIV Positif
}

\author{
Sophia*, Anita Deborah Anwar**, Bony Wiem Lestari***
}

\begin{abstract}
*Diploma Program for Midwifery, Jendral Achmad Yani Health Institute, Cimahi, Indonesia, **Department of Obstetric and Gynecology, Faculty of Medicine, Padjadjaran University, Bandung, Indonesia, ***Department of Epidemiology and Biostatistics, Faculty of Medicine, Padjadjaran University, Bandung, Indonesia
\end{abstract}

DOI: http://dx.doi.org/10.21109/kesmas.v10i4.646

\begin{abstract}
In the developing countries, millions of HIV positive-infected women of childbearing age are currently not using contraceptive to delay or terminate pregnancy. Prevention of unintended pregnancy among HIV positive-infected women is very important to improve these women and their baby's quality of life. This study aimed to analyze factors related to the unmet need among HIV positive-infected women of childbearing age. This study used cross-sectional method with 130 samples taken consecutively. This study was conducted on March 24 to June 30, 2015 at Mawar Clinic in Bandung City. Interviews using a questionnaire were performed to collect data that were then analyzed by using chi square test and multiple logistic regression. The results showed that desire to have children $(\mathrm{OR}=2.67 ; 95 \% \mathrm{Cl}=1.034$ - 6.891, husband's support (OR=7.803;95\% Cl = $2.037-29.884)$ affected the unmet need and husband's HIV status (OR=0.168; $95 \% \mathrm{Cl}=.064-0.44$ ) had lower effect to the unmet need. The husband's support was found as the most influential factor to the unmet need in this study. The husband's role is important in reducing the unmet need among the HIV positive-infected women, so that contraceptive counseling in pair should be performed.
\end{abstract}

Keywords: Contraception, HIV, unmet need, women of childbearing age

\footnotetext{
Abstrak

Jutaan wanita usia subur (WUS) dengan HIV positif di negara berkembang saat ini tidak menggunakan kontrasepsi untuk menunda atau mengakhiri kehamilan. Pencegahan kehamilan yang tidak diinginkan pada WUS dengan HIV positif sangat penting untuk meningkatkan kualitas hidup ibu dan anak. Tujuan penelitian ini untuk menganalisis faktor-faktor yang berpengaruh terhadap unmet need pada WUS dengan HIV positif. Metode penelitian adalah cross sectional dengan sampel berjumlah 130 WUS dengan HIV positif yang diambil secara consecutive sampling. Penelitian di-
}

lakukan pada 24 Maret - 30 Juni 2015 di Klinik Mawar Kota Bandung. Pengumpulan data dilakukan melalui wawancara dengan menggunakan kuesioner, kemudian data dianalisis dengan uji kai kuadrat dan regresi logistik ganda. Hasil penelitian menunjukkan bahwa keinginan memiliki anak dengan $\mathrm{OR}=2,67(\mathrm{Cl} 95 \%=1,034-6,891)$, dukungan suami dengan $\mathrm{OR}=$ 7,803 (CI95\%= 2,037 - 29,884) berpengaruh terhadap unmet need dan status HIV suami dengan OR=0,168 (CI95\%=0,064 - 0,44) berpengaruh lebih rendah untuk terjadi unmet need. Dukungan suami merupakan faktor yang paling berpengaruh terhadap unmet need. Peran suami merupakan faktor penting untuk menurunkan angka unmet need pada WUS dengan HIV positif sehingga disarankan untuk dilakukan konseling kontrasepsi berpasangan.

Kata kunci: Kontrasepsi, HIV, unmet need, wanita usia subur

\section{Introduction}

Millions of women of chilbearing age that do not use contraceptives in preventing pregnancy are the phenomenon that occurs today. The above condition is called as unmet need, a condition in which women of childbearing age do not use contraceptives but want to delay or terminate their pregnancy. ${ }^{1,2}$

The number of unmet need in Indonesia was $11 \%$ (Basic Health Research, 2013). According to the National Family Planning Board (BKKBN) of West Java report, the unmet need by September 2013 was $13.43 \%$ in West Java and $10.68 \%$ in Bandung. ${ }^{3}$ However, there

Correspondence: Sophia, Diploma Program for Midwifery, Jenderal Achmad Yani Health Institute, Cimahi, Terusan Jenderal Sudirman Street Cimahi 40533, Phone: +6222-6631622, email: sophia.maryana@yahoo.com 
was no confirmed data available on the number of unmet need for HIV positive-infected women. A qualitative study was conducted towards 9 women aged 25-33 years who are HIV positive-infected from their partners, which concluded that they did not have intention to have more children, despite not using contraceptives. ${ }^{4}$

Based on the Directorate General of Disease Control and Environmental Health of the Ministry of Health data, in 2013 the number of HIV infections in Indonesia showed an increasing trend from year to year, and the childbearing age of 15 - 49 years is of the highest number of HIV carriers (87.5\%). ${ }^{5}$ Contraceptive use by HIV positive-infected women can prevent pregnancy and help regulate the spacing pregnancies resulting in healthier babies even though the mothers have HIV positive status. The use of contraceptives to prevent unwanted pregnancies in HIV positive-infected women will also prevent transmission of HIV from mother to baby. ${ }^{6-8}$ It can be concluded that the planned pregnancy can improve the quality of life of mother and baby. Information about the unmet needs of HIV positive women is very limited. A preliminary study conducted by the authors towards 10 HIV positive married women of childbearing age from October 9 to 17, 2014. It was found that 6 of them did nor use contraceptives.

Many factors affect the unmet need of HIV positiveinfected women. Several studies have found factors that affect the use of contraceptives among them. Muyindike et al, ${ }^{9}$ multivariately analyzed their study (OR and 95\% $\mathrm{CI}$ ), found age, education, monthly income, number of living children, desire to have children at the age younger than 24 years, secondary education, income, and parity $\geq$ 3 children were significantly associated with the increased of contraceptive use. Desire to have another child among HIV positive-infected women or partners tend to related to the unmet need. 10

Another study carried out by Aziem and Okud, ${ }^{1}$ in Sudan explained by logistic regression analysis showed that the educational and working status of women were related to the unmet need. Educated women have better access to the health facilities and information of contraception. Women's working status can increase women's ability to use the health facilities.

Korra's, ${ }^{8}$ studies towards the results of 13 demographic and health surveys in Ethiopia showed that lack of knowledge, fear of side effects and pair disapproval were the main reasons for not using contraceptives among women. Therefore, this study was conducted in aim to analyze factors that may affect the unmet need of the HIV positive-infected women of childbearing age in Bandung City.

\section{Method}

This survey was non-experimental in which data were collected accidentally. The population of this study were all HIV positive-infected women who came to the Mawar Clinic in Bandung. Respondents as many as 130 were taken accidentally from March to June 2015 by using the formula "rule of thumb". 11

Data were collected by interviews using questionnaires. Interviews were conducted directly to the respondents to obtain information on the individual factors (age, desire to have children as employment, education, income, number of living children, children's HIV positive status, history of marriage), the Family Planning program factor (history of contraception, knowledge of contraception and HIV) and the environmental factors (support of her husband, the husband's HIV status) that affected the unmet need of HIV positive-infected women. The data collected were edited, coded, entried, cleaned, and analyzed using a certain computer statistic package. Univariate, bivariate analysis used chi-square test, meanwhile multivariate analysis used logistic regression test in order to meet the aim of study.

\section{Results}

Reviewing characteristics of respondents as shown in Table 1, the proportion of unmet need were 36 respondents $(27.7 \%)$. The individual factor characteristics among the unmet need group were $91.7 \%$ aged $20-34$ years, $69.4 \%$ still had the desire to have children, $75 \%$ were well-educated, $69.4 \%$ were unemployed, $94.4 \%$ income < regional minimum wage, $77.8 \%$ had $0-2$ living children, $61.1 \%$ had HIV negative-infected children, $55.6 \%$ had no previous marriage history. Within the Family Planning program factor, $91.7 \%$ had non long term conctraceptive method history, $55.6 \%$ had good knowledge about HIV and $63.9 \%$ had less knowledge about family planning. In the environmental factor, $91.7 \%$ had a negative support from husbands and $75 \%$ of husbands HIV status was non-reactive.

Table 1 showed a relation between family planning knowledge, the desire to have children, marriage history, husband support, and the husband's HIV status with the unmet need of the HIV positive-infected women $(\mathrm{p}<$ 0.05).

Based on the final model results as shown in Table 2, variables with $\mathrm{p}$ value $\leq 0,05$ such as negative husband's support, desire to have children, husbands reactive HIV status affected the unmet need of the HIV positive-infected women. Results of logistic regression showed husband's support as the most negative factor related to the unmet need of HIV positive-infected women with OR= 7.803 (2.037 to $29.884 ; 95 \% \mathrm{CI})$.

\section{Discussion \\ Individual Factors}

Age influences someone's knowledge and experiences. 
Table 1. Bivariate Analysis of Factors Influencing Unmet Need of HIV Positive-Infected Women of Childbearing Age

\begin{tabular}{|c|c|c|c|c|c|c|c|c|}
\hline \multirow{2}{*}{ Variabels } & \multirow{2}{*}{ Category } & \multicolumn{2}{|c|}{ Unmet Need $(n=36)$} & \multicolumn{2}{|c|}{ Met Need $(n=94)$} & \multicolumn{2}{|c|}{ Total } & \multirow{2}{*}{ p Value* } \\
\hline & & $\mathbf{n}$ & $\%$ & $\mathbf{n}$ & $\%$ & $\mathbf{n}$ & $\%$ & \\
\hline \multicolumn{9}{|l|}{ Individual Factor } \\
\hline \multirow[t]{2}{*}{ Age } & $\geq 35$ years & 3 & 8.3 & 16 & 17 & 19 & 14.6 & 0.328 \\
\hline & $20-34$ years & 33 & 91.7 & 78 & 83 & 111 & 85.4 & \\
\hline \multirow{2}{*}{ Desire to have children } & Yes & 25 & 69.4 & 43 & 45.7 & 68 & 52.3 & 0.026 \\
\hline & No & 11 & 30.6 & 51 & 54.3 & 62 & 47.7 & \\
\hline \multirow[t]{2}{*}{ Education } & Low & 9 & 25 & 19 & 20.2 & 28 & 21.5 & 0.722 \\
\hline & High & 27 & 75 & 75 & 79.8 & 102 & 78.5 & \\
\hline \multirow{2}{*}{ Employment status } & Unemployed & 25 & 69.4 & 60 & 63.8 & 85 & 65.4 & 0.692 \\
\hline & Employed & 11 & 30.6 & 34 & 36.2 & 45 & 34.6 & \\
\hline \multirow[t]{2}{*}{ Income level } & $<$ Reg min wage & 34 & 94.4 & 83 & 88.3 & 117 & 90 & 0.514 \\
\hline & $\geq$ Reg min wage & 2 & 5.6 & 11 & 11.7 & 13 & 10 & \\
\hline \multirow[t]{2}{*}{ None of living children } & $>2$ & 8 & 22.2 & 17 & 18.1 & 25 & 19.2 & 0.774 \\
\hline & $0-2$ & 28 & 77.8 & 77 & 81.9 & 105 & 80.8 & \\
\hline \multirow[t]{2}{*}{ HIV positive-infected children } & Yes & 14 & 38.9 & 30 & 31.9 & 44 & 33.8 & 0.586 \\
\hline & No & 22 & 61.1 & 64 & 68.1 & 86 & 66.2 & \\
\hline \multirow[t]{2}{*}{ Marriage history } & Ever & 16 & 44.4 & 23 & 24.5 & 39 & 30 & 0.044 \\
\hline & Never & 20 & 55.6 & 71 & 75.5 & 91 & 70 & \\
\hline \multicolumn{9}{|l|}{ Family planning program factor } \\
\hline \multirow[t]{2}{*}{ Contraception history } & Non long-term method & 33 & 91.7 & 84 & 89.4 & 117 & 90 & 1.000 \\
\hline & Long-term method & 3 & 8.3 & 10 & 10.6 & 13 & 10 & \\
\hline \multirow[t]{2}{*}{ Knowledge on HIV } & Bad & 16 & 44.4 & 48 & 51 & 64 & 49.2 & 0.632 \\
\hline & Good & 20 & 55.6 & 46 & 48.9 & 66 & 50.8 & \\
\hline \multirow[t]{2}{*}{ Knowledge on FP } & Bad & 23 & 63.9 & 34 & 36.2 & 57 & 43.8 & 0.008 \\
\hline & Good & 13 & 36.1 & 60 & 63.8 & 73 & 56.2 & \\
\hline \multicolumn{9}{|l|}{ Environmental factor } \\
\hline \multirow[t]{2}{*}{ Husband's support } & Negative & 33 & 91.7 & 52 & 55.3 & 85 & 65.4 & 0.000 \\
\hline & Positive & 3 & 8.3 & 42 & 44.7 & 45 & 34.6 & \\
\hline \multirow[t]{2}{*}{ Husband's HIV status } & Reactive & 9 & 25 & 61 & 64.9 & 70 & 53.8 & 0.000 \\
\hline & Non-reactive & 27 & 75 & 33 & 35.1 & 60 & 46.2 & \\
\hline
\end{tabular}

Note: *based on chi-square test

Table 2. Multivariate Final Model of Factors Affecting Unmet Need of HIV Positive-Infected Women of Childbearing Age

\begin{tabular}{lcccl}
\hline Variable & B Coef & SE & p Value** & OR (95\%CI) \\
\hline Negative husband's support & 2.054 & 0.685 & 0.003 & $7.803(2.037-29.884)$ \\
Desire to have children & 0.982 & 0.484 & 0.042 & $2.670(1.034-6.891)$ \\
Husband's HIV reactive/positive status & 1.785 & 0.492 & 0.000 & $0.168(0.64-0.440)$ \\
\hline Constanta & -4.077 & & & \\
\hline
\end{tabular}

Note : **Based on logistic regression, model accuracy $75,4 \%$

Knowledge and experience are increasing along age, affecting someone's reasoning and mindset, resulting in better knowledge gained. The older someone is, the more mature he is in thinking and behaving. ${ }^{12-14}$

Age influence to a person's health behavior, is also influenced by another factor among others that is by knowledge. One's knowledge relation with the reasoning towards information is related to age, particularly in the mental abilities required to learn and adapt towards new situations, such as remembering ever learned, analogy reasoning and creative thinking reached at its peak at the age of twenties. 15

The above statement is not consistent with the results of this study in which a group of unmet need HIV positive-infected women, who were at the age of 20-34 years $(91.7 \%)$. In this study, the age variable was not related to the unmet need of the HIV positive-infected women. However, there were some studies supporting these findings, such as a study conducted by Habte and Namasasu, ${ }^{16}$ that confirmed that the age factor was not related to the use of contraceptive.

Anther factor that influenced the unmet need is the desire to have children. Multivariable analysis showed that there was relation between the respondent and her partner's desire to have children with the the unmet need. By $69.4 \%$ of respondents and their husbands still had a desire to have the children. This finding was supported by Okigbo's, ${ }^{10}$ study explaining that the desire to have children among the HIV positive-infected women and their husbands tend to result in the unmet need. 
Multivariate analysis of study, Anand et al, ${ }^{17}$ in Africa found that HIV-infected women who did not want to have children were 3.73 times more likely to use modern contraceptives than those who have the desire. The results showed that education was not related to the unmet need among the HIV positive-infected women. By $75 \%$ of respondents in the group of unmet need had high education level (high school, higher education). The result was not in with Aziem and Okud's, ${ }^{1}$ research in Sudan which found that the education status of women affect the unmet need in Family Planning. Educated women had better access to the health facilities and information regarding contraception. However Wanyenze's, ${ }^{18}$ study suggested through bivariate analysis, that education, income, marriage history are not related to the unmet need for family planning among HIV-infected women ( $p>$ $0.05)$. The finding also showed that there is no relation between employment status and unmet need, but $69.4 \%$ of respondents of ths unmet need group were unemployed/housewives. Aziem's, ${ }^{1}$ study explained that working women could improve the ability to use health facilities compared to those who were not.

Gustiana's, ${ }^{19}$ study found that working was an important factor in influencing women's attitude to the use of contraceptive reflecting the women and decision-making autonomy. Women who worked out of the home had more opportunities to access contraception services.

HIV positive-infected women who also have HIV positive-infected children status tend to be the unmet need. This finding was supported by studies found that the unmet need was more common among HIV positiveinfected women who had HIV positive-infected children died of AIDS. ${ }^{20}$ This study found that $38.9 \%$ of the unmet need respondents had HIV positive-infected children. This study finding was more interesting when link to the prevention of new HIV virus infection. The key strategy in minimizing the incidence of HIV infection, particularly in reducing transmission from mother to infant is by reducing the unmet need for family planning. Reducing the unmet need for family planning is also the key component to to globally prevent new HIV infections.

High income was found significantly related to increase of contraseptive use. ${ }^{9,18}$ Low welfare level among HIV positive-infected women tend to cause their need for contraceptive were unmet in terminating and planning their pregnancy. ${ }^{21}$ This study found that $94.4 \%$ of respondents whose their need were unmet were those belong to the less income.

Unmet need is also more common among HIV positive-infected women who had ever married. ${ }^{22}$ HIV positive-infected woman who had more than 2 couples was more at at risk for unmet need than just having one. ${ }^{18}$ Based on multivariate analysis, Kim Chi et al, 23 found that married women had increased use of contraceptive odd ratio 7 times compared to women who had never married or have ever been married. The study illustrated the $44.4 \%$ of the unmet need respondents had ever married before. This was because the new husband desired to have children although the respondents already had children from her marriage before.

The study showed that the respondents in the unmet need group were those who had two children (22.2\%). This finding was supported by Muyindike et al, ${ }^{9}$ that suggested parity more than three was related to the increase of contraceptive use by HIV positive-infected women. Several factors found related in this study were similar to the findings of study cunducted by Habte and Namasasu. Education, occupation, income, marriage history were not related to the use of contraceptives. ${ }^{16}$

\section{Family Planning Program Factor}

Nattabi's, ${ }^{24}$ study found that increase of contraceptive use by HIV positive-infected women was related to good knowledge of Family Planning. Similarly, Gustiana, ${ }^{19}$ also found that of all respondents knowing about modern contraceptive methods, $75.4 \%$ of them were using contraceptive and $24.6 \%$ were not.

Knowledge is very important in determining health status. It can affect a person's decision-making in health. Decision-making is defined as the selection among the various alternatives concerning choices. In general, the decision-making is related to a person's behavior in response to any information received. The decision is the result of a thinking process considering various factors to be carried out or realized. 25

In relation to this study, knowledge plays as important role for a HIV positive-infected woman to make decision to use contraceptive. However, in this study, there was no relation between knowledge of the unmet need among HIV positive-infected women. The finding above was probably caused by other factors that had more influence to the unmet need compared to knowledge.

Contraceptive use experience can contribute to the unmet need of HIV positive-infected women. Women who had been using hormonal contraceptive, injectable and pill hormonal contraceptive previously had greater possibility to unmet need. This was because of experiences in side effects that scared them to reuse the contraceptive. ${ }^{26,27}$ This finding is in line with the fact that $97.7 \%$ of respondents whose their need unmet had previously used hormonal contraceptives.

\section{Environmental Factor}

Nearly all $(33 \%)$ of the 36 unmet need respondents obtained negative husband support in contrast with the respondents who their need were met, most of 94 respondents whose (87 respondents) obtained positive hus- 
band's support. The finding was supported by several studies, including by Mekonnen and Worku, ${ }^{28}$ that explained that the use of contraceptives was 2.6 times higher among women whose partners supported the use of contraceptive.

One form of husband's support is discussion about contraception. Nakaie's, ${ }^{29}$ study in 2011 reported that a woman who held discussions with her partner about the use of contraceptive method was six times more likely to use contraceptive. According to Victor, ${ }^{22}$ discussion between husband and wife about family planning related to the unmet need because of good communication between partners was correlated with increasing use of contraceptive.

Study conducted by Mahmoud, 27 explained that the husband resistance is an important risk factor for the occurrence of unmet need. Approximately $21.3 \%$ of the resistance of the women obtained resistance from their husbands compared to those whose their need met $(6.3 \%)$.

At the couple level, barriers like a ban or a negative attitude of women in using modern contraceptive is a theory for an increase in the unmet need for contraception. Despite the contraceptive method used is oriented towards woman, in fact every woman still have to get approval from the husband. This situation is perceived worse by HIV positive-infected women, in which they are more disadvantaged by stigma in the community. 10

A qualitative study conducted by Nattabi, ${ }^{24}$ in Africa, explained that partner/or husband's rejection was one of the barriers to the contraceptive use, whenever the respondent could not use contraceptive because of severe side-effects. Male domination in decision-making regarding fertility and contraceptive use resulted in the husband made decision-making.

Husband's HIV status influenced the unmet need. A husband with HIV reactive status had higher risk of giving unmet need than HIV non-reactive. This finding was in line with several studies which claimed that the partner's non reactive HIV status might increase HIV positive-infected women's participation of contraception.9,29 Jhangri's, ${ }^{20}$ study confirmed that the unmet need for family planning was more common among HIV positive-infected woman who had HIV positive status couples compared to those whose partner were HIV negative. ${ }^{20}$

The findings of studies above are different from this study in which the husband's HIV status among the most unmet need respondents (75\%) were non-reactive/negative. This study concludes that the use of contraceptive is an important element for a pair with HIV positive wives who can plan a pregnancy properly and to prevent new HIV infections.

\section{Conclusion}

In conclusion, desire to have children, negative hus- band's support and husband's HIV reactive status are related to the unmet need of HIV positive-infected women.

\section{Recommendation}

Since the husband's role is important in the Family Planning unmet need, family planning counseling should be provided in order to reduce the unmet need among HIV positive-infected women.

\section{Acknowledgement}

A sincere gratitude are given to Dr. Farid Husin, Ir., dr., SpOG (K)., Kes., MH.Kes., Dr. Tita Husnitawati Madjid, dr., SpOG (K), Rovina Ruslami, dr., SpPD., Ph.D., who have provided inputs into the study and writing of this article.

\section{References}

1. Aziem A, Okud A. Factors affecting unmet need for family planning in Eastern Sudan. BMC Public Health 2013;13 (102): 1-4.

2. McCoy S, Buzdugan R, Ralph L, Mushavi A, Mahomva A, Hakobyan A, et al. Unmet need for family planning, contraceptive failure, and unintended pregnancy among HIV-infected and HIV-uninfected women in Zimbabwe. Plos One. 2014; 9(8): 1-7.

3. Badan Penelitian dan Pengembangan Kesehatan. Riset kesehatan dasar 2013. Jakarta: Kementerian Kesehatan Republik Indonesia; 2013.

4. Oktavia M, Alban A, Zwanikken P. A qualitative study on HIV positive women experience in PMTCT program in Indonesia. Retrovirology. 2012; 9(suppl 1): 119.

5. Kementerian Kesehatan Republik Indonesia. Laporan situasi perkembangan HIV dan AIDS di Indonesia tahun 2013.Jakarta: Kementerian Kesehatan Republik Indonesia; 2013.

6. Mbonye A, Hansen K, Wamono F, Magnussen P. Barriers to contraception among HIV-positive women in a periurban district of Uganda. International Journal of STD \& AIDS. 2012; 23: 661-6.

7. Bradleya H, Tsuia A, Gillespiea K. HIV infection and contraceptive need among female Ethiopian voluntary HIV counseling and testing clients. AIDS Care. 2010; 22(10): 1-3.

8. Korra A. Attitudes toward family planning and reasons for nonuse among women with unmet need for family planning in Ethiopia. Calverton, Maryland USA; ORC Macro; 2002.

9. Muyindike W, Fatch R, Steinfield R, Matthews L, Musinguzi N, Emenyonu N, et al. Contraceptive use and associated factors among women enrolling into HIV care in Southwestern Uganda. Infectious Diseases in Obstetrics and Gynecology. 2012; 2012: 340782.

10. Okigbo C, McCarraher D, Chen M, Gwarzo U, Vance G, Chabikuli O. Unmet need for contraception among clients of FP/HIV integrated services in Nigeria: the role of partner opposition. African Journal of Reproductive Health. 2014; 18 (2): 1-7.

11. Dahlan S. Besar sampel dan cara pengambilan sampel dalam penelitian kedokteran dan kesehatan. Jakarta: Salemba Medika; 2013. p.101-08.

12. Mubarak WL. Promosi kesehatan untuk kebidanan. Jakarta: Salemba Medika; 2011.

13. Notoatmodjo S. Promosi kesehatan dan ilmu perilaku. Jakarta: Rineka Cipta; 2012. 
14. Green LW, Kreuter MW, Deeds SG, Partridge KB. Perencanaan pendidikan kesehatan. Sebuah pendekatan diagnostik. Mamdy Z, Tafal Z, Kresno S. Jakarta: Universitas Indonesia; 2011.

15. Azwar S. Sikap manusia (teori dan pengukuran). Yogyakarta: Pustaka Pelajar; 2007.

16. Habte D, Namasasu J. Family planning use among women living with HIV: knowing HIV positive status helps-results from a national survey. Reproductive Health. 2015; 12 (41): 1-11

17. Anand A, Shiraishic RW, Bunnelld RE, Jacobse K, Solehdinc N, AbdulQuaderc A. Knowledge of HIV status, sexual risk behaviors and contraceptive need among people living with HIV in Kenya and Malawi. AIDS. 2009; 23(12): 1567-72.

18. Wanyenze R, Matovu J, Kamya M, Tumwesigye N, Nannyonga M, Wagner G. Fertility desires and unmet need for family planning among HIV Infected Individuals in two clinic with differing models of family planning service delivery. BMC Women's Health. 2015; 15 (5): 1-12.

19. Gustiana R. Factors associated with contraceptive discontinuation in Indonesia. Bangkok: Mahidol University. 2010.

20. Jhangri G, Heys J, Alibhai A, Rubaale T, Kipp W. Unmet need for effective family planning in HIV-infected individuals: results from a survey in Rural Uganda. Journal of Family Planning Reproductive Health Care. 2012; 38: 23-9.

21. Adair T. Desire for children and unmet need for contraception among HIV positive in Lesotho. DHS WOrking Papers No. 32. Calverton, Maryland, USA: Macro International; 2007.

22. Akelo V, Girde S, Borkowf CB, Angira F, Achola K, Lando R, et al.
Attitudes toward family planning among HIV-positive pregnant women enrolled in a prevention of mother-to-child transmission study in Kisumu, Kenya. PLOS ONE. 2013; 8(8): 1-4.

23. Chi B, Gammeltoft T, Han N, Rasch V. Contraceptive use among HIVpositive women in Quang Ninh Province, Vietnam. Tropical Medicine and International Health. 2012; 17(10): 1-4.

24. Nattabi B, Li J, Thompson S, Orach C, Earnest J. Family planning among people living with HIV in post-conflict Northern Uganda: A mixed methods study. Conflict and Health. 2011; 5(18): 1-9.

25. Universitas Sumatera Utara. Konsep perilaku dan HIV/AIDS. Medan: Perpustakaan Universitas Sumatera Utara; 2008.

26. Bekele T, Gebremariam A, Tura P. Factors Associated with contraception discntinuation in Agarfa District, Bale Zone, South East Ethiopia. Epidemiology. 2015; 5 (1): 1-9.

27. Mahmoud M, Bakr I, Ismail N, Arafa N, El-Gewaily M. Women in Cairo, Egypt and their risk factors for unmet contraceptive need: a community-based study. Journal of Family Planning and Reproductive Health Care. 2015; 37: 26-31.

28. Mekonnen W, Worku A. Determinants of low family planning use andhigh unmet need in Butajira District, South Central Ethiopia. Reproductive Health. 2011; 8 (37):1-6.

29. Nakaie N, Tuon S, Nozaki I, Yamaguchi F, Sasaki, Kakimoto K. Family planning practice and predictors of risk of inconsistent condom use among HIV-positive women on anti-retroviral therapy in Cambodia. BMC Public Health. 2014; 14(170): 1-9. 